\title{
SERUM MALONDIALDEHYDE LEVELS AND SUPEROXIDE DISMUTASE ACTIVITIES IN PULMONARY TUBERCULOSIS AND LUNG CANCERS
}

\author{
Yıldız Güney ${ }^{1}$, Ayse Bilgihan ${ }^{2}$, Tansu Ulukavak Ciftçi ${ }^{3}$, Filiz Çimen $^{4}$, Ozgür Coşkun $^{4}$
}

\section{ABSTRACT \\ SERUM \\ LEVELS \\ DISMUTASE \\ MALONDIALDEHYDE SUPEROXIDE ACTIVITIES PULMONARY TUBERCULOSIS AND LUNG CANCERS}

Objectives: An increasing amount of epidemiological and experimental evidence has been carried out on the relationship between free radical activity and malignancy. The imbalance between free radical production and cellular defense mechanisms has been described in cancers and degenerative diseases like tuberculosis (tb).

Methodology: The present investigation has been undertaken to study the levels of lipid peroxide (LP) and antioxidant enzyme superoxide dismutase (SOD) activities in sera of lung cancers (Lc) and tb. Forty-two patients and fourteen healthy cases were enrolled into the study. Group I had seventeen subjects with Lc, group II had twenty-five patients with tb and group III had fourteen healthy cases. The malondialdehide (MDA) and superoxide dismutase (SOD) activities in sera were quantified.

Results: Serum MDA levels in the whole group of patients ( $\mathrm{Lc}$ and $\mathrm{tb}$ ) were much higher than in healthy controls. The levels of MDA did not change significantly in the group I vs. group II $(\mathrm{p}>0,05)$. The SOD activity in sera from patients with Lc was markedly lower than the other two groups. Activities of SOD in group I significantly decreased as compared to the group II $(p<0,001)$. In the present study although LP levels increased in both tb and Lc patients, the activities of SOD in Lc cases were significantly higher than tb patients.

Key Words: lung cancers, tuberculosis, lipid peroxidation, superoxide dismutase

\section{ÖZET}

Akciğer Tüberkulozu ve Akciğer Kanserli Hastalarda Serum Malondialdehid Seviyesi ve Süperoksid Dismutaz Aktivitesi

Giriş: Artan orandaki epidemiyolojik ve deneysel çalışmalar serbest radikal aktivitesi ile malignensi arasında yakın ilişki olduğunu göstermiştir. Kanser ve tüberkuloz (tb) gibi dejeneratif hastal1klarda serbest radikal oluşumu ile hücresel savunma mekanizması arasındaki dengesizlik tariflenmiştir.

Yöntem: Bu çalışmada akciğer kanserli (Ac Ca) ve tb'lu hastaların serumlarında lipid peroksid seviyesi ve antioksidan bir enzim olan süperoksit dismutaz aktivitesi incelenmiştir. Kırkiki hasta ve ondört sağl1klı gönüllü bu çalışmaya dahil edilmiştir. Malondialdehid (MDA) ve superoksid dismutaz (SOD) aktivitesi serumlarında tespit edildi.

Sonuçlar: Serum MDA seviyeleri tüm hasta grubunda (Ac $\mathrm{Ca}$ ve tb) kontrol grubuna gore daha yüksek bulunmuştur. MDA düzeylerinde grup I ile grup II arasında belirgin fark göstermemektedir $(\mathrm{p}>0,05)$. Ac Ca'li hastaların serumlarında incelenen SOD aktivitesi diğer iki gruba göre belirgin olarak düşüktür. Grup I'deki SOD aktivitesi grup II

\footnotetext{
${ }^{1}$ Department of Radiation Oncology, Ankara University Hospital, Ankara, Turkey

${ }^{2}$ Department of Biochemistry, Gazi University Hospital, Ankara, Turkey

${ }^{3}$ Department of Chest Diseases, Gazi University Hospital, Ankara, Turkey

${ }^{4}$ Atatürk Chest Diseases and Chest Surgery Hospital, Ankara, Turkey
} 
ile karşılaştırıldığında anlamlı azalma tespit edilmiştir $(p<0,001)$. Bu çalışmada, LP seviyesi hem tb'li hem de Ac Ca'li hastalarda yüksek olmasına karşın, SOD aktivitesi Ac Ca'li hastalarda tb'lu hastalara göre belirgin yüksektir.

Anahtar Sözcükler: Akciğer kanserleri, tuberkuloz, lipid peroksidasyon, superoksid dismutaz

\section{1- INTRODUCTION}

The formation of highly reactive oxygencontaining molecular species is a normal consequence of a variety of essential biochemical reactions. In healthy conditions at the cellular level, there is a critical balance exists between the free radical generation and the antioxidant defense. The range of antioxidant defenses available within the cell and in the extracellular should be adequate to protect against oxidative damage. Oxidative modification of DNA, proteins and lipids by reactive oxygen species (ROS) play a role in disease, including inflammatory disease and cancer (1). An increasing amount of epidemiological and experimental evidence has been carried out on the relationship between free radical activity and malignancy $(1,2)$. Several investigators have reported that oxidants may be involved in the early events of carcinogenesis, including transformation and promotion $(3,4)$. The critical target of ROS is presumed to be cellular DNA. ROS may act as carcinogenic agents by inducing structural changes in DNA and modulating stress gene expression (5). In animal models, antioxidant molecules have been shown to inhibit experimental carcinogenesis (6) Very little is known about the respiratory tract antioxidant defenses of patients with lung cancer, although superoxide dismutase (SOD) can prevent in vitro carcinogenesis.

Also the imbalance between free radical production and cellular defense mechanisms has been described in degenerative lung diseases like tuberculosis (tb) (7). Mycobacterium tuberculosis is intracellular pathogens, which grow and replicate in the host macrophages. It is well known that macrophages undergo respiratory burst after contact with this microorganism. These cells posses the capacity to generate huge amounts of ROS and ROS induce lipid peroxidation
(LP), a chain process which affects unsaturated fatty acids mainly localized in cell membranes, in which end product as malondialdehide (MDA) is generated (8). MDA, which is itself responsible for some of the damaging effects of free radicals on DNA and on cell membranes (9).

Lipid peroxidation products diffuse from the site of inflammation and can be measured in the blood (10).

Both cancer and tuberculosis are associated with lung oxidant-antioxidant imbalance. Because of this, in the present study the levels of MDA and antioxidant enzyme SOD activities in sera of lung cancers were studied and compared with tuberculosis and healthy cases. And it was to establish whether MDA levels and SOD activities in sera might be used as markers for diagnostic and/or prognostic in these diseases.

\section{2- PATIENTS AND METHODS}

\subsection{Patients and blood samples}

During the period from December 2000 to May 2001 forty-two patients treated in the Atatürk Chest Diseases and Chest Surgery Hospital were enrolled into the study. Investigation was classified into three groups as follow;

Grop I consisted of 17 patients with lung cancer (1 women, 16 men with a mean age of $54,3 \pm 14,1)$

Group II consisted of 25 patients with tuberculosis (4 women, 21 men with a mean age of $48,3 \pm 13,2)$

Group III (control group) consisted of 14 healthy cases ( 3 women, 11 men with a mean age of $51,0 \pm 9,7$ )

(Table 1). All the cases were subjected to through clinical examination and investigation.

Table I: MDA (nmol/ml) levels in 3 groups

\begin{tabular}{|l|c|c|}
\hline & Mean $( \pm \mathrm{SD})$ & \\
\hline Group I & $32,92 \pm 14,89$ & \\
\hline Group II & $28,43 \pm 9,83$ & \\
\hline Group III & $15,95 \pm 3,9$ & \\
\hline Group I-III & & $\mathrm{P}<0,001^{*}$ \\
\hline Group II-III & & $\mathrm{P}<0,01^{*}$ \\
\hline Group I-II & & $\mathrm{p}>0,05$ \\
\hline
\end{tabular}

SD: standard deviation

* statistically significant $\mathrm{p}<0,05$ 
The study was approved by the ethical committee. All patients and healthy volunteers in this study gave their informed consent before entering the study. Serum was obtained from venous blood drawn in the fasting state before breakfast and it was stored frozen at -30 $\mathrm{C}$ until the analyse was performed.

\subsection{Lipid Peroxidation (LP)}

LP is a chain reaction that involves the oxidation of polyunsaturated fatty acids in membranes induced by free radicals and is an indicator of oxidative cell damage. Direct measurement of oxidative stress in humans is difficult because the active oxygen species and free radicals are extremely short-lived (11). Instead, products of the oxidative process are measured.

LP products were measured as an index of MDA production, in blood by the method of Yoshioka (12). In this reaction, MDA which reacts with tiobarbituric acid (TBA) reagent under acidic conditions to generate a pink colored product and determined at $532 \mathrm{~nm}$.

The results are given as $\mathrm{nmol} \mathrm{MDA} / \mathrm{ml}$. Tetramethoxypropane (sigma T9889) was used as an external standart. (SOD)

\subsection{Estimation of superoxide dismutase}

SOD activity was assayed according to the method of Sun et al (13). In this method, xanthine-xanthine oxidase system was used to generate a superoxide flux, and nitroblue tetrazolium (NBT) was used as an indicator of superoxide production. SOD activity was then measured by the degree of inhibition of the reaction unit of enzyme provides 50\% inhibition of NBT reduction. Results are expressed as $\mathrm{U} / \mathrm{ml}$.

\subsection{Statistics}

Kruskal-Wallis (nonparametric ANOVA test was used for the statistical analysis anc Dunn's multiple comparison test was performed as post-hoc test.

\section{RESULTS}

Serum MDA levels in the whole group of patients (Lc and tb) were much higher than in healthy controls. (n: 17)

Lung cancers were included in the group I
Pulmonary tuberculosis were collected in the group II (n: 25).

Healthy cases were collected in the group III (n: 14)

Fig I presents the progressive increase in serum concentrations of MDA groups I, II and III. Patients in group I had the highest levels of MDA. There was a significant increase in MDA levels in the group I $(32,93 \pm 3,61)$ than in the group III $(15,95 \pm 1,04)(p<0,001)$. Also it was determined a significant increase in MDA levels in the group II $(28,43 \pm 1,96)$ than in the group III $(15,95 \pm 1,04)(\mathrm{p}<0,01)$.

Figure I: MDA (nmol/ml) levels in 3 groups Group I: lung cancer, Group II: pulmonary tuberculosis, Group III: healthy cases

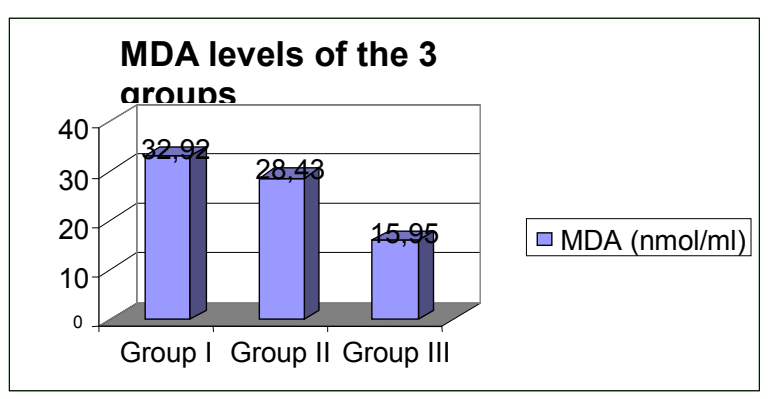

Figure II: SOD activities (U/ml) in 3 groups Group I: lung cancer, Group II: pulmonary tuberculosis, Group III: healty cases

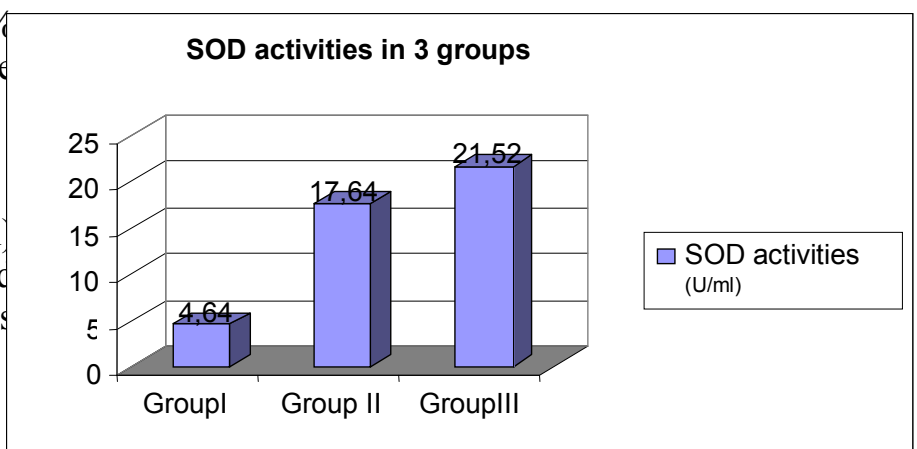

The levels of MDA did not change markedly in the group I vs. group II $(p>0,05)$ (Table 1). 
Fig II represents the activities of antioxidant enzyme SOD in the group I, II and III. The SOD activity in sera from patients with lung cancer was markedly lower than the other two groups.

The activities of SOD, which was found to be, decreased significantly in group I when compared to group III $(4,64 \pm 0,26$ vs. $21,52 \pm 1,49 ; \mathrm{p}<0,001)$.

Patients in group II exhibited lower activities of SOD when compared with group III $(17,64 \pm 0,93$ vs $21,52 \pm 1,49 ; p<0,05)$.

Patients from group I had the lowest activities of SOD and when compared group II to group $\mathrm{I}$, there was a significant increase $(17,64 \pm 0,93$ vs $4,64 \pm 0,26) \quad(p<0,001)$ (Table 2).

Table II: SOD activities (U/ml) in $\mathbf{3}$ groups

\begin{tabular}{|l|c|c|}
\hline & Mean $( \pm \mathrm{SD})$ & \\
\hline Group I & $4,64 \pm 1,10$ & \\
\hline Group II & $17,64 \pm 4,67$ & \\
\hline Group III & $21,52 \pm 5,58$ & \\
\hline Group I-III & & $\mathrm{P}<0,001^{*}$ \\
\hline Group II-III & & $\mathrm{P}<0,05^{*}$ \\
\hline Group I-II & & $\mathrm{P}<0,001^{*}$ \\
\hline
\end{tabular}

\section{SD: standard deviation}

Statistically significant $\mathrm{p}<0,05$

\section{DISCUSSION}

Severe oxidative stress can cause cell injury and death (1). In the lung, free radical production has been described in different cancers, lung injury, pulmonary emphysema and tuberculosis $(10,14,15,16)$. The close relationship between free radical formation and malignancy has been documented (17). It has been reported that human tumour cells shown to produce large amounts of hydrogen peroxide (18). Increased ROS production cause higher levels of DNA lesions in malignant cells, which may contribute to metastatic potential of tumours (19). Increased lipid peroxidation in abnormally proliferation cells are said to be released into the systemic circulation resulting in increased MDA levels in cancer patients as observed in our study. Earlier reports described elevated plasma MDA levels not only in cancer patients but also from patients with some other diseases such as pulmonary tuberculosis (10). During pulmonary inflammation increased amounts of ROS are produced as a consequence of phagocyte respiratory burst. One of the manifestations of these free radical-mediated processes is lipid peroxidation (20). Our data indicated that MDA levels were increased in tuberculosis. In this study MDA levels were found to be increased both lung cancer patients and tuberculosis patients. And the levels of serum MDA of lung cancer patients were not statistical different compared with tuberculosis patients.

In several studies, decreased serum SOD activities were reported in cancer patients $(21,22)$. SOD is an important antioxidant enzyme catalyzing conversion reaction of superoxide radical to hydrogen peroxide and molecular oxygen. Enzyme has two forms, cytoplasmic (Cu,Zn-SOD) and mitochondrial (Mn-SOD) superoxide dismutase (23). Several investigators have reported that in lung cancerous tissue the activities of antioxidant enzymes were generally lower than in normal lung tissue (24). In our study, we observed that significant decrease in SOD activities in lung cancer patients leads to a net increase in the level of the superoxide free radical. The increase in LP observed may be due to pulmonary tuberculosis or carcinogenesis induced by ROS. The parallel decrease in SOD could be due to inactivation by ROS (25). Recently, it has been observed that free radicals attack proteins, mainly enzymes (DT36) (26). Hence it is assumed that the decrease in activities of SOD in our present study might be due to the increased free radical attack i.e. due to elevated lipid peroxidation products (MDA) in sera of cancer patients. Similarly we have found decreased SOD activities in tuberculosis patients but the activities of SOD in lung cancer cases were significantly lower than tuberculosis patients. These lower activities of SOD might have caused the accumulation of O2- in cancer patients (27). This can lead to elevated reactive oxygen metabolites resulting in damage to the key subcellular structure such as DNA, cell membranes, and other vital cellular components. 
Although the activities of SOD in lung cancer cases were significantly lower than tuberculosis patients, decreased activities of SOD are specific neither for lung cancer nor for tuberculosis. Similarly increased MDA levels are specific neither for lung cancer nor for tuberculosis. Therefore, we do not believe that SOD activities and MDA levels of serum can be used as specific diagnostic markers. However, decreased SOD activities and increased MDA levels might serve as nonspecific markers indicating increased oxidative stress in these diseases.

\section{REFERENCES}

1. Halliwell B. Reactive oxygen species in living systems: Source, biochemistry and role in human disease. Am J Med 1991; 91: 14-21.

2. Jung K, Seide 1B, Rudolph B et al. Antioxidant enzymes in malignant prostate cell lines and in primary cultured prostatic cells. Free Radical Biol Med 1997; 23: 127-33.

3. Hochstein P, Atallah AS. The nature of oxidants and antioxidant systems in the inhibition of mutation and cancer. Mutat Res 1988; 202: 363-75.

4. Timothy RR, Sharma HM. Free radicals in health and disease. Indian J Clin Pract 1991; 2: 15-25.

5. Cerutti PA. Oxyradicals and cancer. Lancet 1994; 344: 862-3.

6. Menkes MS, Comstock GW, Vuilleumier JP, Helsing KJ, Rider AA, Brookmeyer R. Serum betacarotene, vitamins A and E, selenium and the risk of lung cancer. N Engl J Med 1986; 315: 1250-4.

7. De Oliveira HG, Rosatto ER, Prolla JC. Pleural fluid adenosine deaminase and lymphocyte proportion: Clinical usefulness in the diagnosis of tuberculosis. Cytopathology 1994; 5: 27-32.

8. Janero DR. Malondialdehyde and thiobarbituric acid reactivity as diagnostic indices of lipid peroxidation and peroxidative tissue injury. Free Radical Biol Med 1990; 9: 515-40.

9. Penn ZJ, Steer PJ. Breech presentation. In: James DK, Steer PJ, Weiner CP, Gonik B (eds). High risk Pregnancy. Management options. London: WB Saunders 1996: 173-198.

10. Kwiatkowska G, Piasecka MZ, Piotrowta W and Nowata D. Increased serum concentrations of conjugated diens and malondialdehyde in patients with pulmonary tb. Resp Med 1999; 93: 272-6.

11. Pryor WA, Godber SS. Noninvasive measures of oxidative stress status in humans. Free Rad Biol Med 1991; 10: 177-184.

12. Yoshika T, Kawada K, Shimada T, Moru M. Lipid peroxidation in maternal and cord blod and protective mechanisms against activated oxygen toxicity in the blood. Am J Obstet Gynecol 1979; 135: 372-6.

13. Yi-Sun, Larry W Oberley and Ying Li. A simple method for clinical assay of superoxide dismutase. Clin Chem 1988; 3413: 497-500.

14. Durak İ, Canbolat O, Kavutçu M, Öztürk HS; Yurtarslanı Z. Activities of total, cytoplasmic and mitochondrial superoxide dismutase enzymes in sera and pleural fluids from patients with lung cancer. J Clin Lab Anal 1996; 10: 17-20.

15. Ward PA, Till GO, Hathermill J, Annesley T.M, Kunbel PG. Systemic complement activation, lung injury and products of lipid peroxidation. J Clin Invest 1985; 76: 517-527.

16. Janoff A. Investigation into the biochemical mechanisms of pulmonary emphysema: effects of cigarette smoke on enzymes and antienzymes in the lung. Respiration 1986; 50 (suppl 1); 13-25.

17. Dormandy TL: Free-Radical oxidation and antioxidants. Lancet 1978; 1: 647-53.

18. Sztrowski TP, Nathan CF. Production of large amounts of hydrogen peroxide by human tumor cells. Cancer Res 1991; 51: 794-8.

19. Jaruga P, Zastawny TH, Skokowski J, Dizdaroğlu M, Olinsky R. Oxidation DNA base damage and antioxidant enzyme activities in human lung cancer. FEBS letters 1994; 341: 59-64.

20. Demling R, Lalonde C. Relationship between lung injury and lung lipid peroxidation caused by recurrent endotoxemia. Am Rev Respir Dis 1989: 139: 1118-24.

21. Kwee JK, Mitidien E. Alfonso OR: Lowered superoxide dismutase in highly metastatic B 16 melanoma cells. Cancer Lett 1991 57: 199-202.

22. Bhuvarahamarthy V, Balasubramanian N, Govindasamy S. Effect of radiotherapy and chemoradiotherapy on circulating antioxidant system of human uterine cervical carcinoma. Molecular and cellular Biochemistry 1996; 158: 17-23.

23. McCord JM. Fridovich I. Superoxide dismutase. An enzyme function for erythrocuprein (hemocuprein). J Biol Chem 1969; 244: 6049-55. 
24. Zieba M, Suwalski M, Kwiatkowska S et al. Comparison of hydrogen peroxide generation and the content of lipid peroxidation products in lung cancer tissue and pulmonary parenchyma. Respir Med 2000; 94(8): 800-5.

25. Steaper SD, Fabris M, Ferrari V, Carbonare MO, Leon A. Quercatin protects cutaneous tissueassociated cell types including sensory neurons from oxidative stress induced by glutathione depletion: cooperative effects of ascorbic acid. Free Radical Biology and Medicine 1997; 222(4): 669-678.

26. Comporti M. Biology of disease: lipid peroxidation and cellular damage in toxic liver injury. Lab Invest 1985; 53: 599-623.

27. Vanisree AJ, Shyamaladevi CS. Status of lipid peroxidation and antioxidant enzymes in malignant (bronchogenic carcinoma) and non-malignant pleura effusions. Indian Journal of cancer 1999; Vol 36: 127-134. 